\title{
KETERAMPILAN BERPIKIR TINGKAT TINGGI SISWA SEKOLAH MENENGAH PERTAMA DALAM MATA PELAJARAN MATEMATIKA
}

\author{
Samritin \\ Program Studi Pendidikan Guru Sekolah Dasar, Fakultas Keguruan dan Ilmu Pendidikan, \\ Universitas Muhammadiyah Buton, Jl. Betoambari No. 36 Baubau. \\ E-mail: samritin75@gmail.com
}

\begin{abstract}
Abstrak
Penelitian ini bertujuan untuk mengukur kemampuan berpikir tingkat tinggi (KBTT) siswa SMP dalam mata pelajaran matematika. Penelitian ini menggunakan teknik testing (pengujian) yang melibatkan 913 siswa SMP di Ibukota Kabupaten Muna. Tes yang digunakan telah diketahui memiliki bukti validitas, reliabilitas tinggi, dan parameter butir yang baik. Data yang diperoleh dalam penelitian ini adalah data kuantitatif. Data dianalisi secara deskriptif kuantitatif. Berdasarkan hasil analisis diperoleh simpulan bahwa: (1) reliabilitas hasil pengukuran sangat tinggi (2) kemampuan higher order thinking siswa SMP dalam mata pelajaran masih rendah yang ditunjukkan oleh persentase siswa yang berada pada kategori kemampuan rendah dan sangat rendah sebanyak $66,05 \%$, sedangkan siswa yang mencapai kategori tinggi dan sangat tinggi hanya sebanyak 33,95\%, (3) persentase siswa yang mencapai kemampuan tinggi dan sangat tinggi di SMPN 4 Raha lebih tinggi dibandingkan siswa SMP lainnya, (4) rata-rata skor setiap sekolah berada di bawah rata-rata ideal.
\end{abstract}

Kata kunci: KBTT, Pengukuran, Matematika.

\begin{abstract}
This study aimes to measure Higher Order Thinking Skills (HOTS) Junior High School Students in Mathematics. This study was used testing technique that involving 913 junior high school students in Muna Regency. The tests used are known to have proof of validity, high reliability, and good grain parameters. Data obtained in this research is quantitative data. Data was analyzed by descriptive quantitative. The results of analyses of this study concluded that: (1) the reliability of the measurement results is very high (2) ability of students' higher order thinking SMP is still low, that indicated by the percentage of students who are in the category of low and very low ability as much as $66.05 \%$, while students who achieve a high and very high categories just as much as $33.95 \%$, (3) the percentage of students achieved the ability high and very high in SMPN 4 Raha are higher than other junior high students, (4) the average score of each school is under the ideal average.
\end{abstract}

Keywords: HOTS, measurements. Mathematics. 


\section{SANG PENCERAH}

Volume 3, Nomor 1, Februari 2017, Hlm. 50-62

Samritin: Keterampilan Berpikir Tingkat Tinggi Siswa ...

\section{Pendahuluan}

Berpikir merupakan proses kognitif yang digunakan untuk memahami (Limbach \& Waugh, 2013: 2) sesuatu. Proses kognitif terjadi bila ada kaitan antara informasi baru dengan pengetahuan yang telah dimiliki seseorang. Untuk memahami sesuatu diperlukan proses transformasi informasi baru melalui penilaian, abstraksi, penalaran, imaginasi, dan sebagainya. Setiap individu mengalami proses kognitif sesuai kondisi dan pengalamannya. Dengan demikian maka keterampilan berpikir setiap orang dapat berkembang sesuai dengan pengalamannya. Keterampilan berpikir akan berkembang dengan baik bila seseorang tidak terisolasi dari lingkungan. Anak-anak yang dibesarkan terpisah dari masyarakat menunjukkan tingkat keterbelakangan perkembangan sosial, emosional dan intelektual (Womack, 1988: 9). Hal ini berarti bahwa keterampilan berpikir manusia hanya akan berkembang dalam lingkungan yang kondusif. Di sekolah, keterampilan berpikir dapat berkembang dengan baik apabila pembelajaran yang dilaksanakan didesain untuk memfasilitasinya.

Dalam pembelajaran, mengarahkan pikiran siswa pada solusi baru atau alternatif-alternatif solusi suatu masalah akan mempengaruhi kualitas siswa (Limbach \& Waugh, 2013: 2). Oleh karena itu, sangat penting bagi guru untuk memfasilitasi pengembangan keterampilan berpikir siswa melalui berbagai cara. Salah satu cara yang dapat ditempuh guru adalah pemberian masalah atau tugas-tugas. Siswa perlu dibiasakan berpikir untuk menemukan solusi suatu masalah dengan berbagai situasi yang berbeda. Keterampilan berpikir dapat dibedakan dalam dua tingkatan yaitu keterampilan Berpikir Tingkat Rendah (KBTR) dan Keterampilan Berpikir Tingkat Tinggi (KBTT). Para pakar memberikan definisi yang berbeda-beda tentang kedua tingkatan tersebut. Wang \& Wang (2010: 1) mengemukan bahwa KBTT atau Higher
Order Thinking Skills (HOTS) adalah proses berpikir lebih dari menghafal dan pemahaman, dan melibatkan berbagai proses kognitif, seperti meringkas, mengidentifikasi, melakukan eksplorasi, menilai hasil, dan sebagainya. McMahon (2009: 270) mendefinisikan KBTT sebagai proses mental yang memungkinkan siswa untuk mengembangkan pengetahuan faktual, prosedural, konseptual dan metakognisi dalam domain berpikir kritis dan kreatif. Unsur-unsur KBTT dalam kedua pendapat ini berkaitan dengan proses mental yang melibatkan tiga level terakhir taksonomi Bloom, dan sejalan dengan pendefinisian dari pakar-pakar lainya misalnya Hopson, et al., 2001: 110; Sezer, 2008: 349; Bissel \& Lomens, 2006; Sutherland (2006: 108), Snyder \& Snyder (2008: 91), Remirez (2008: 24), dan Moore \& Stanley (2010: 10).

KBTT bukan menghafal atau mengingat tetapi melibatkan siswa pada tingkat pemikiran yang tinggi untuk mendorong siswa menjadi kreator ide-ide baru, analis informasi dan mengkonstruksi pengetahuan (McCurry, 2013: 2). KBTT dalam matematika mencakup dengan keterampilan koneksi, memecahkan masalah, dan penalaran matematika (Samritin, 2016, p.93). Koneksi adalah keterampilan untuk melihat dan membuat hubungan antarkonsep matematika, antara matematika dengan objek-objek lain, dan antara matematika dengan situasi nyata (Kaur \& Lam, 2012: 2). Memecahkan masalah berarti menemukan tindakan (Polya, 1981: 117) yang berupa solusi. Tugas atau soal dikatakan sebagai masalah bila memuat tantangan yang mana tidak ada prosedur tertentu yang dapat diterapkan secara langsung untuk menemukan penyelesaiannya. Jawaban benar suatu masalah dapat berupa jawaban tunggal atau lebih. Demikian juga cara menyelesaikannya, dapat ditempuh dengan berbagai cara atau mungkin hanya satu cara 


\section{SANG PENCERAH}

Volume 3, Nomor 1, Februari 2017, Hlm. 50-62

Samritin: Keterampilan Berpikir Tingkat Tinggi Siswa ...

saja. Hal ini tergantung pada jenis masalah diselesaikan. Untuk memutuskan strategi atau teorema mana yang dipilih ketika menyelesaikan suatu masalah atau membuktikan suatu pernyataan, harus didasarkan pada informasi yang diketahui atau yang bersumber dari apa yang diketahui serta sifat-sifat Matematika yang relevan. Tanpa pemahaman yang jelas tentang informasi yang diperlukan untuk memecahkan suatu masalah atau pembuktian suatu pernyataan, maka kesimpulan yang benar sulit untuk dihasilkan.

Penalaran matematika adalah keterampilan yang melibatkan pengumpulan bukti, membuat dugaan, generalisasi, menyusun argumen, dan menarik kesimpulan logis (Peressini \& Webb, 1999: 156). Sementara itu Russel (1999: 1) mengemukakan bahwa penalaran matematika mencakup wawasan matematis, penilaian dan generalisasi matematis. Pencapaian kemampun penalaran matematika terlihat dari keterampilan melakukan matematisasi, menganalisis, menilai, komunikasi, melakukan interpretasi, mengembangkan model dan strategi sendiri, membuat argumen, dan generalisasi.

Pengembangan KBTT merupakan salah satu tujuan pembelajaran matematika Sekolah Menengah Pertama (SMP). Untuk itu, pembelajaran dan pengukuran hasil belajar Matematika SMP haruslah mendorong pengembangan keterampilan berpikir tingkat tinggi siswa. KBTT dalam mata pelajaran matematika sangat penting untuk diukur. Hasil pengukuran tersebut memberikan informasi tentang tentang kekuatan dan kelemahan siswa dalam memahami dan menerapkan matematika. Dengan demikian, hasil pengukuran tersebut sangat dibutuhkan dalam perencanaan perbaikan atau peningkatan kualitas hasil belajar di kelas. Di samping itu, hasilnya juga dapat digunakan untuk memetakan dan menentukan siswa untuk berbagai kepentingan misalnya untuk pemberian "waktu belajar tambahan" bagi siswa tertentu, serta promosi keterampilan siswa untuk even-even tertentu di berbagai tingkatan, dan sebagainya.

Hasil pengukuran KBTT pada wilayah tertentu dapat digunakan untuk membandingkan keterampilan siswa antarsekolah. Hal ini dapat dimanfaatkan oleh pengambil keputusan di daerah untuk membuat kebijakan-kebijakan yang mampu mendorong dan meningkatkan kualitas pendidikan. Dengan demikian, hasil pengukuran di bidang pendidikan dapat memberikan kontribusi yang bermanfaat dalam upaya mencapai tujuan pendidikan nasional. Berdasarkan latar belakang di atas, permasalahan yang dikaji dalam penelitian ini adalah bagaimanakah keterampilan berpikir tingkat tinggi siswa SMP dalam mata pelajaran matematika?

Tujuan penelitian ini adalah untuk memperoleh hasil pengukuran keterampilan berpikir tigkat tinggi siswa SMP dalam mata pelajaran Matematika.

\section{Metode Penelitian}

Penelitian ini dilakukan menggunakan teknik testing (pengujian). Untuk mencapai tujuan tersebut prosedur yang digunakan dalam penelitian ini, yaitu (1) memilih instrumen pengukuran yang sesuai; (2) menentukan subjek penelitian; (3) menentukan waktu penelitian; (4) melakukan pengujian; (5) melakukan pemeriksaan/menyekor jawaban siswa; (6) melakukan analisis keterampilan, dan (7) melakukan interpretasi terhadap hasil analisis. Penelitian ini diksanakan pada tanggal 10 Desember 2015 di Kabupaten Muna Propinsi Sulawesi Tenggara. Penelitian ini melibatkan 913 siswa kelas VIII SMP sebagai subjek. Siswa yang menjadi subjek penelitian berasal dari lima SMP di Ibu Kota Kabupaten. 


\section{SANG PENCERAH}

Volume 3, Nomor 1, Februari 2017, Hlm. 50-62

Samritin: Keterampilan Berpikir Tingkat Tinggi Siswa ...

\section{Data, Instrumen, dan Teknik Pengumpulan Data}

Data yang diperoleh dalam penelitian ini adalah data kuantitatif yang berupa data skor hasil tes keterampilan berpikir tingkat tinggi siswa pada Mata Pelajaran Matematika SMP. Untuk memperoleh data tersebut digunakan instrumen yang berbentuk tes tertulis. Tes yang digunakan yaitu tes yang telah dikembangkan menggunakan prosedur pengembangan instrumen. Tes tersebut mengukur KBTT siswa SMP Kelas VIII pada materi/sub materi seperti yang tercantum pada Tabel1.

Tabel 1 Materi/Sub Materi, Kompetensi Dasar dan Aspek Keterampilan pada Tes

\begin{tabular}{lcl}
\hline \multicolumn{1}{c}{$\begin{array}{c}\text { Pokok } \\
\text { Bahasan }\end{array}$} & $\begin{array}{c}\text { Kompetensi } \\
\text { Dasar }\end{array}$ & \multicolumn{1}{c}{$\begin{array}{c}\text { Jenis } \\
\text { Keterampilan }\end{array}$} \\
\hline $\begin{array}{l}\text { Operasi pada } \\
\text { Bentuk Aljabar } \\
\text { Relasi dan Fungsi }\end{array}$ & 1.1 & Koneksi \\
& 1.3 & $\begin{array}{l}\text { Koneksi, Pemecahan } \\
\text { Masalah dan Penalaran } \\
\text { Matematika }\end{array}$ \\
Nilai Fungsi & 1.4 & $\begin{array}{l}\text { Koneksi, Pemecahan } \\
\text { Masalah dan Penalaran } \\
\text { Matematika } \\
\text { Koneksi }\end{array}$ \\
$\begin{array}{l}\text { Persamaan Garis } \\
\text { Lurus }\end{array}$ & 1.6 & $\begin{array}{l}\text { Pemecahan Masalah } \\
\text { Sistem Persamaan } \\
\text { Linear Dua } \\
\text { Variabel }\end{array}$ \\
\hline
\end{tabular}

Instrumen tersebut diperoleh melalui proses pengembangan secara sistematis menurut prosedur pengembangan instrumen. Reliabilitas instrumen yang diperoleh dari dua kali uji coba sangat tinggi dan relatif konsisten yakni 0.87 dan 0.88 . Instrumen juga memiliki bukti validitas isi dan validitas konstruk. Proses validasi instrumen dilakukan kualitatif dan secara kuantitatif. Secara kualitatif, validitas isi instrumen diperoleh melalui diskusi antara perancang tes dengan pakar pengukuran dan pendidikan matematika melalui forum Focus Group Discussion (FGD) dan dilanjutkan dengan diskusi melalui teknik Delphy. Secara kuantitatif validitas isi instrumen diperoleh dari penilaian kuantitif dari para pakar yang anggota FGD ditambah dengan satu pakar pendidikan matematika dari Universitas Negeri Yogyakarta. Berdasarkan hasil penilaian kuantitatif dari para pakar diperoleh indeks validitas setiap butir tes paling rendah 0.833 dan berdasarkan analisis hasil uji coba diperoleh instrumen instrumen dinyatakan valid.

\section{Teknik Analisis Data}

Data penelitian ini merupakan data kuantitatif berupa skor hasil tes. Data yang diperoleh dalam penelitian ini dianalisis secara deskriptif kuantitatif. Analisis dilakukan untuk memperoleh informasi akurasi pengukuran dan klasifikasi keterampilan peserta siswa. Akurasi pengukuran dilihat dari derajat agreement (reliabilitas) antarpenilai dan reliabilitas konsistensi internal. Reliabilitas antarpenilai digunakan persentase agreement, sedangkan reliabilitas konsistensi internal digunakan formula alpha dari Cronbach. Kriteria penerimaan reliabilitas hasil pengukuran mengacu pada kriteria Nunnally (1981: 245) dan Urbina (2004: 137) yaitu paling rendah 0.70. Secara matematis formula alpha sebagai berikut:

$$
\alpha=\frac{k}{k-1} \frac{\sigma-\sum \sigma_{x i}}{\sigma}
$$

Keterangan.

$\mathrm{k}=$ panjang tes, $\sigma=$ varians skor total dan $\sigma_{x i}$ $=$ varians skor pada butir ke-i.Klasifikasi keterampilan siswa mengadaptasi klasifikasi dari Azwar (2009: 108). Secara teknis, analisis data dilakukan menggunakan bantuan software komputer Microsoft Office Excel 2010 dan SPSS versi 16.0. 


\section{SANG PENCERAH}

Volume 3, Nomor 1, Februari 2017, Hlm. 50-62

Samritin: Keterampilan Berpikir Tingkat Tinggi Siswa ...

\section{Pembahasan}

Setelah pelaksanaan pengujian, lembar jawaban seluruh testee diskor. Penskoran jawaban testee menggunakan skor politomus karena instrumen yang digunakan berbentuk tes uraian dengan skala 0 - 2 dan 0 - 3. Pemberian skor mengacu pada rubrik penskoran. Penskoran jawaban testee dilakukan oleh dua orang. Hal ini dimaksudkan untuk menghindari berbagai efek subjektivitas menyekoran, misalnya efek lelah, efek halo, tulisan yang "jelek/indah", dan sebagainya. Penskoran dilakukan menurut butir. Penskoran butir berikutnya dilakukan bila jawaban semua testee pada butir tertentu sudah tuntas diskor. Penggunaan teknik penskoran ini dapat menghindari kemungkinan ketidakkonsistenan dalam pemberian skor.

Setelah kedua penilai memberikan skor kepada seluruh jawaban peserta tes, reliabilitas antarpenilai diestimasi. Estimasi reliabilitas antar penilai dimaksudkan untuk mengetahui derajat konsistensi antarpenilai dalam memberikan skor. Reliabilitas antarpenilai diestimasi menggunakan ukuran kesepakatan menurut Kappa (measure of agreement Kappa). Estimasi reliabilitas antarpenilai dilakukan dengan bantuan software komputer SPSS 16. Hasil estimasi reliabilitas diperoleh bahwa koefisien reliabilitas mencapai 0,99. Koefisien tersebut melampaui batas minimal reliabilitas, yakni 0,70. Hal ini berarti bahwa hasil pengukuran sangat konsisten dengan derajat perbedaan sangat kecil.

Meskipun perbedaan skor dari kedua penilai memiliki nilai yang sangat kecil, tetapi untuk mengkaji keterampilan peserta tes diperlukan skor tunggal. Untuk itu, dilakukan penelusuran terhadap skor-skor yang berbeda yang diberikan oleh kedua penilai. Setelah skor-skor yang berbeda ditemukan, selanjutnya dikonfirmasi dan didiskusikan bersama kedua penilai, sampai diperoleh skor tunggal. Berdasarkan skor tunggal yang diperoleh, reliabilitas hasil pengukuran diestimasi. Estimasi relibilitas digunakan formula alpha dari Cronbach. Estimasi varians dan koefisien alpha dilakukan menggunakan bantuan Hasil estimasi reliabilitas diperoleh koefisien alpha sebesar 0.87. Koefisien tersebut cukup tinggi dan melampaui batas minimal penerimaan reliabilitas suatu pengukuran yakni 0.70 .

Berdasarkan koefisien reliabilitas tersebut, selanjutnya standard error of measurement (SEM) diestimasi. SEM suatu pengukuran diharapkan memiliki nilai yang rendah. Semakin rendah nilai SEM maka tingkat kepercayaan terhadap hasil pengukuran semakin tinggi. Dalam CTT skor seorang peserta tes merupakan skor komposit dari skor murni dan kesalahan yang dinyatakan sebagai $X=T+E$. Artinya skor yang diperoleh seseorang masih belum menggambarkan skor yang sebenarnya tetapi masih dipengaruhi oleh kesalahan. Dengan diketahuinya SEM, maka skor murni (true score) seorang peserta tes dapat diperkirakan.

Secara matematis SEM diformulasikan sebagai $S_{E}=S_{x} \sqrt{ } 1-r_{x x^{\prime}}$ (Allen \& Yen, 1979: 89; Nunnally, 1981: 239; Haertel, 2006: 70; Fraenkel \& Wallen, 2008: 159). Hasil estimasi SEM diperoleh $S_{E}=2,68$. Menurut Allen \& Yen (1979: 92) berdasarkan nilai SEM ( $\left.\mathrm{S}_{\mathrm{E}}\right)$ dapat dibuat confidence-interval for true score (CITS) peserta tes sebagai berikut:

$$
X-Z_{c} S_{E} \leq T \leq X+Z_{c} S_{E}
$$

atau dapat ditulis:

$$
\mathrm{X} \pm \mathrm{Z}_{\mathrm{c}} \mathrm{S}_{\mathrm{E}}
$$

Keterangan.

$\mathrm{X}=$ observed score, $\mathrm{S}_{\mathrm{E}}=$ standard error of measurement, $\mathrm{Z}_{\mathrm{C}}=$ critical value of the standard normal at the sired probability level (Allen \& Yen, 1979: 90). Berdasarkan hasil estimasi SEM yang diperoleh di atas, maka pada tingkat kepercayaan 90\%, CITS seorang peserta tes dengan skor $X$ yaitu $X \pm$ 


\section{SANG PENCERAH}

Volume 3, Nomor 1, Februari 2017, Hlm. 50-62

Samritin: Keterampilan Berpikir Tingkat Tinggi Siswa ...

$(1,65)(2,68)$ atau $X \pm 4,43$. Jika seorang peserta memiliki skor $(X)=20$, maka skor sebenarnya peserta tes tersebut berada pada interval $20 \pm 4,43$ atau dari 15,57 sampai 24,43. Skor hasil pengukuran KBTT siswa setiap sekolah disajikan pada Tabel 3 dan Gambar 1.

Tabel 2 Skor KBTT setiap Sekolah

\begin{tabular}{|c|c|c|c|c|c|}
\hline \multirow[b]{2}{*}{$X$} & \multicolumn{5}{|c|}{ Frekuensi } \\
\hline & $\begin{array}{c}\text { SMPN } 1 \\
\text { Raha }\end{array}$ & $\begin{array}{c}\text { SMPN } 2 \\
\text { Raha }\end{array}$ & $\begin{array}{l}\text { SMPN } \\
3 \text { Raha }\end{array}$ & $\begin{array}{c}\text { SMPN } 4 \\
\text { Raha }\end{array}$ & $\begin{array}{c}\text { SMPN } 5 \\
\text { Raha }\end{array}$ \\
\hline 0 & 1 & 0 & 0 & 0 & 0 \\
\hline 1 & 1 & 0 & 2 & 2 & 2 \\
\hline 2 & 9 & 2 & 1 & 4 & 4 \\
\hline 3 & 15 & 18 & 7 & 7 & 1 \\
\hline 4 & 10 & 10 & 7 & 9 & 9 \\
\hline 5 & 11 & 14 & 1 & 9 & 7 \\
\hline 6 & 15 & 20 & 6 & 9 & 6 \\
\hline 7 & 11 & 23 & 5 & 12 & 3 \\
\hline 8 & 8 & 21 & 8 & 10 & 4 \\
\hline 9 & 7 & 10 & 6 & 4 & 8 \\
\hline 10 & 15 & 4 & 2 & 5 & 3 \\
\hline 11 & 11 & 15 & 1 & 1 & 3 \\
\hline 12 & 16 & 16 & 2 & 4 & 6 \\
\hline 13 & 11 & 16 & 2 & 7 & 3 \\
\hline 14 & 9 & 10 & 5 & 0 & 6 \\
\hline 15 & 10 & 16 & 2 & 3 & 5 \\
\hline 16 & 8 & 5 & 6 & 8 & 8 \\
\hline 17 & 2 & 12 & 2 & 7 & 4 \\
\hline 18 & 12 & 16 & 4 & 4 & 1 \\
\hline 19 & 10 & 6 & 2 & 6 & 1 \\
\hline 20 & 4 & 7 & 3 & 3 & 1 \\
\hline 21 & 8 & 3 & 0 & 3 & 3 \\
\hline 22 & 9 & 13 & 2 & 8 & 5 \\
\hline 23 & 9 & 15 & 0 & 6 & 1 \\
\hline 24 & 7 & 16 & 1 & 11 & 2 \\
\hline 25 & 8 & 9 & 0 & 8 & 1 \\
\hline 26 & 3 & 13 & 0 & 5 & 0 \\
\hline 27 & 8 & 11 & 1 & 3 & 0 \\
\hline 28 & 0 & 6 & 0 & 0 & 0 \\
\hline 29 & 0 & 3 & 0 & 0 & 0 \\
\hline 30 & 1 & 0 & 0 & 0 & 0 \\
\hline 31 & 0 & 1 & 0 & 0 & 0 \\
\hline Jumlah & 249 & 331 & 78 & 158 & 97 \\
\hline
\end{tabular}

Tabel 3 dan Gambar 1 menunjukkan bahwa skor tertinggi yang dicapai siswa adalah 31. Skor tertinggi tersebut 2 kurangnya dari skor ideal yang dapat dicapai siswa yakni 33. Hal ini berarti bahwa siswa yang memiliki skor tertinggi yang hanya mampu mencapai $86.11 \%$ skor KBTT dalam matematika. Skor 31 hanya dicapai oleh dua peserta tes atau kurang dari $1 \%$. Pada tabel dan gambar di atas juga terlihat bahwa terdapat $0,11 \%$ siswa yang memperoleh skor 0 dan sebanyak 8 orang atau $0,9 \%$ memperoleh skor 1 . Skor 0 merupakan skor terendah di SMPN 1 Raha, sedangkan skor 1 merupakan skor terendah di SMP Negeri 3, SMPN 4, dan SMPN 5 Raha. Sementara itu skor terendah di SMPN 2 Raha adalah skor 2. Skor-skor terendah tersebut menunjukkan bahwa di setiap sekolah ada siswa yang tidak mampu menjawab dengan baik soal-soal berpikir tingkat tinggi dalam matematika.

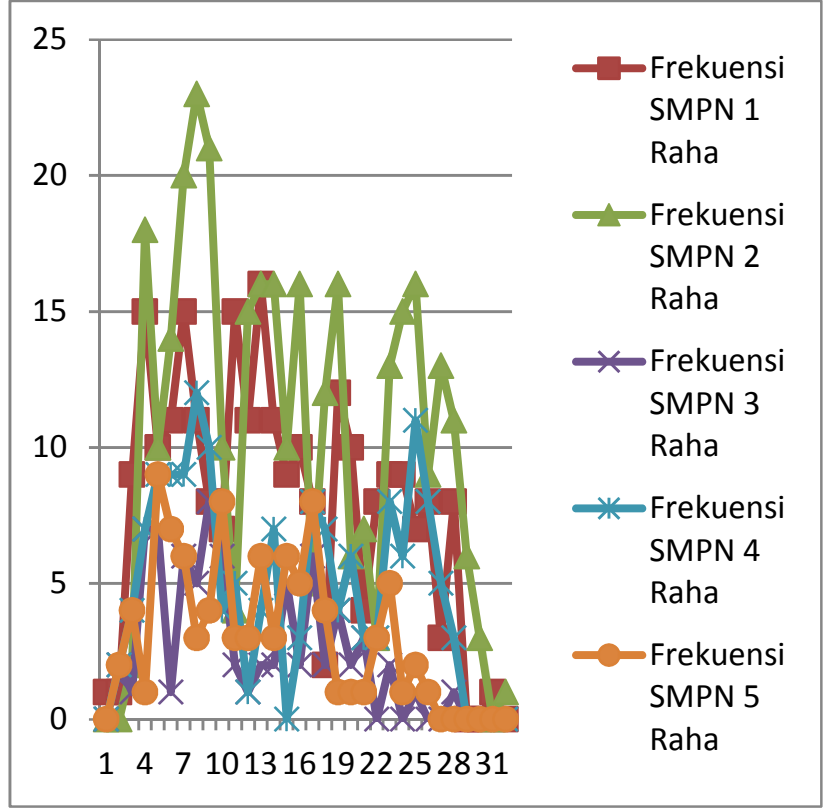

Gambar 1 Grafik Skor KBTT Siswa Setiap Sekolah

Hasil pengukuran KBTT peserta tes dapat disajikan dalam bentuk bilangan atau dalam bentuk predikat. Penyajian dalam bentuk bilangan dimaksudkan untuk memudahkan pengompositan hasil pengukuran tersebut dengan hasil pengukuran lainnya. Untuk mengompositkan hasil-hasil pengukuran, semua hasil pengukuran harus ditempatkan pada skala yang sama. Hal ini tergantung pada kebutuhan sekolah atau pengguna hasil pengukuran. Apabila dikehendaki skala pengukuran 0 - 100 maka setiap hasil pengukuran harus ditransformasi ke dalam skala 0 - 100 sebelum dikompositkan. 


\section{SANG PENCERAH}

Volume 3, Nomor 1, Februari 2017, Hlm. 50-62

Samritin: Keterampilan Berpikir Tingkat Tinggi Siswa ...

Demikian juga apabila dikehendaki skala 0 10.

Transformasi hasil pengukuran ke dalam skala tertentu dapat dilakukan menggunakan transformasi linier dengan cara membagi skor perolehan dengan skor ideal kemudian hasilnya dikalikan 10 untuk memperoleh nilai pada rentang 0 - 10 atau dikalikan 100 untuk memperoleh nilai pada rentang 0 - 100. Pada rentang $0-10$, nilai yang diperoleh siswa yang mengikuti tes keterampilan higher order thinking siswa SMP dalam mata pelajaran matematika tertinggi adalah 9,39 dan terendah adalah 0,00. Pada rentang $0-100$, nilai yang diperoleh siswa yang mengikuti tes keterampilan higher order thinking siswa SMP dalam mata pelajaran matematika tertinggi adalah 93,93 dan terendah adalah 0,00 .

Hasil penilaian keterampilan higher order thinking siswa SMP dalam mata pelajaran matematika juga dapat disajikan dalam bentuk predikat sangat rendah sampai sangat tinggi. Untuk menghasilkan nilai dalam bentuk predikat, dapat dilakukan dengan cara membuat kategorisasi skor. Tes keterampilan higher order thinking dalam penelitian ini memiliki skor maksimum 33 dan skor minimum 0 . Dengan demikian rentangan skor sebesar 33, dan nilai rata-rata ideal sebesar 16,5. Rentangan tersebut dibagi ke dalam enam satuan simpangan baku, diperoleh bilangan 5,5 sebagai simpangan baku ideal. Berdasarkan rata-rata ideal $\left(\overline{\mathrm{X}}_{\mathrm{i}}\right)$ dan simpangan baku ideal $\left(\mathrm{S}_{\mathrm{i}}\right)$ tersebut kategorisasi keterampilan higher order thinking siswa SMP dalam mata pelajaran matematika adalah sebagai berikut:

a. $\bar{X}_{\mathrm{i}}+1,5 \mathrm{~S}_{\mathrm{i}}<\mathrm{X}$ atau $24,75<\mathrm{X}$; kategori sangat tinggi

b. $\bar{X}_{i}<X \leq \bar{X}_{i}+1,5 S_{i}$ atau $16,50<X \leq 24,75$; kategori tinggi

c. $\overline{\mathrm{X}}_{\mathrm{i}}-1,5 \mathrm{~S}_{\mathrm{i}}<\mathrm{X} \leq \overline{\mathrm{X}}_{\mathrm{i}}$ atau $8,25<\mathrm{X} \leq 16,5$; kategori rendah d. $X \leq \bar{X}_{i}-1,5 S_{i}$ atau $X \leq 8,25$; kategori sangat rendah

Berdasarkan karegorisasi di atas, profil higher order thinking skills siswa SMP dalam mata pelajaran matematika secara keseluruhan dan masing-masing sekolah dapat dilihat pada tabel 4 berikut:

Tabel 3 Capaian KBTT Berdasarkan Kategori

\begin{tabular}{ccccc}
\hline \multirow{2}{*}{ Sekolah } & \multicolumn{4}{c}{ Kategori (dalam \%) } \\
\cline { 2 - 5 } & $\begin{array}{c}\text { Sangat } \\
\text { Tinggi }\end{array}$ & Tinggi & Rendah & $\begin{array}{c}\text { Sangat } \\
\text { Rendah }\end{array}$ \\
\hline SMPN 1 Raha & 8,03 & 24,50 & 34,94 & 32,53 \\
SMPN 2 Raha & 12,99 & 26,59 & 27,79 & 32,63 \\
SMPN 3 Raha & 1,28 & 17,95 & 33,33 & 47,44 \\
SMPN 4 Raha & 10,13 & 30,38 & 20,25 & 39,24 \\
SMPN 5 Raha & 1,03 & 18,56 & 43,30 & 37,11 \\
\hline Keseluruhan & $\mathbf{8 , 8 7}$ & $\mathbf{2 5 , 0 8}$ & $\mathbf{3 0 , 5 6}$ & $\mathbf{3 5 , 4 9}$ \\
\hline
\end{tabular}

Pada tabel 3 terlihat bahwa pada setiap sekolah, peserta tes didominasi oleh yang memiliki keterampilan rendah dan sangat rendah dengan persentase masing-masing $67,47 \%, 60,42 \%, 80,77 \%, 59,49 \%$, dan $80,41 \%$. Secara keseluruhan peserta tes juga tampak didominasi oleh peserta tes yang memiliki keterampilan rendah dan sangat rendah yaitu sebanyak $66,05 \%$ atau hanya sebanyak $33,95 \%$ peserta tes yang memiliki keterampilan tinggi dan sangat tinggi. Hal ini menunjukkan bahwa peserta tes memiliki KBTT dalam mata pelajaran matematika yang cenderung rendah.

Hasil analisis terhadap data skor diperoleh rata-rata 13,22 dan skewness kurva distribusi bernilai positif yaitu 0,30. Nilai skewness positif menggambarkan bahwa kurva distribusi tidak normal tetapi condong ke kanan atau kurva memiliki ekor yang panjang ke kanan. Rata-rata skor tersebut menyimpang ke kiri sejauh 3,28 skor ratarata ideal $(16,5)$. Hal ini berarti bahwa absis titik puncak kurva distribusi berada pada titik atau skor 13,22 bukan pada titik atau skor rata-rata ideal. Pergeseran absis titik puncak kurva ke kiri mengakibatkan ekor kurva memanjang ke kanan. Ketidaknormalan suatu kurva Kurva distribusi skor disajikan pada gambar 2 . Suatu kurva distribusi condong ke kanan 


\section{SANG PENCERAH}

Volume 3, Nomor 1, Februari 2017, Hlm. 50-62

Samritin: Keterampilan Berpikir Tingkat Tinggi Siswa ...

berarti bahwa skor-skor rendah (skor-skor di sebelah kiri rerata ideal) yang digambarkan pada kurva mendominasi skor-skor tinggi (skor yang berada di sebelah kanan rata-rata ideal).

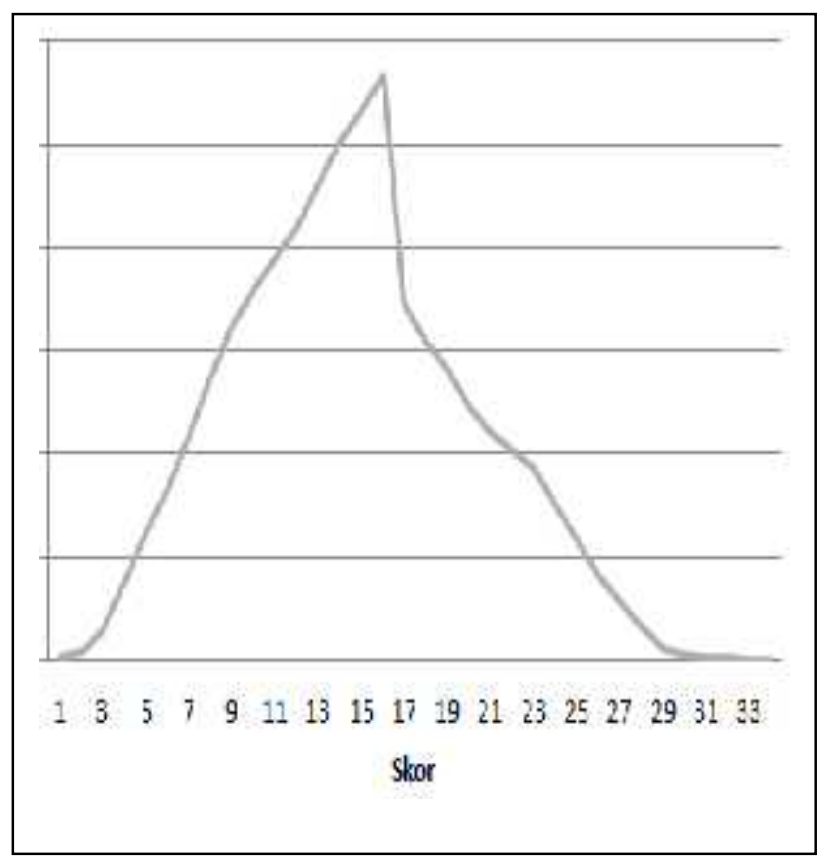

\section{Gambar 2 Kurva distribusi KBTT}

Pada gambar 3 terlihat bahwa ekor kurva distribusi miring ke kanan. Kurva distribusi mendatar dan rapat dengan sumbu $Y=0$ mulai dari skor 32 sampai skor 33. Hal ini menunjukkan bahwa kedua skor tersebut masing-masing memiliki frekuensi 0 . Kondisi ini terlihat jelas pada gambar 4 .

Gambar 4 menunjukkan bahwa skor 6 memiliki frekuensi terbesar (yakni 56) dibandingkan frekuensi skor lainnya. Skor dengan frekuensi tertinggi berikutnya berturut-turut yaitu skor 7 sebanyak 54, skor 8 sebanyak 51, dan disusul oleh skor 3 sebanyak 48. Frekuensi-frekuensi besar lainnya dimiliki lebih banyak dimiliki skor di bawah skor rata-rata ideal dibandingkan skor-skor di atas skor rata-rata ideal. Hal ini sangat berpengaruh pada rendahnya persentase peserta tes yang mencapai predikat tinggi dan sangat tinggi.

Untuk mengetahui penyebab dominannya skor-skor rendah selanjutnya dilakukan penelusuran terhadap skor perolehan pada setiap setiap sub materi yang diujikan. Hasil penelusuran disajikan pada Tabel 4 dan Gambar 3.

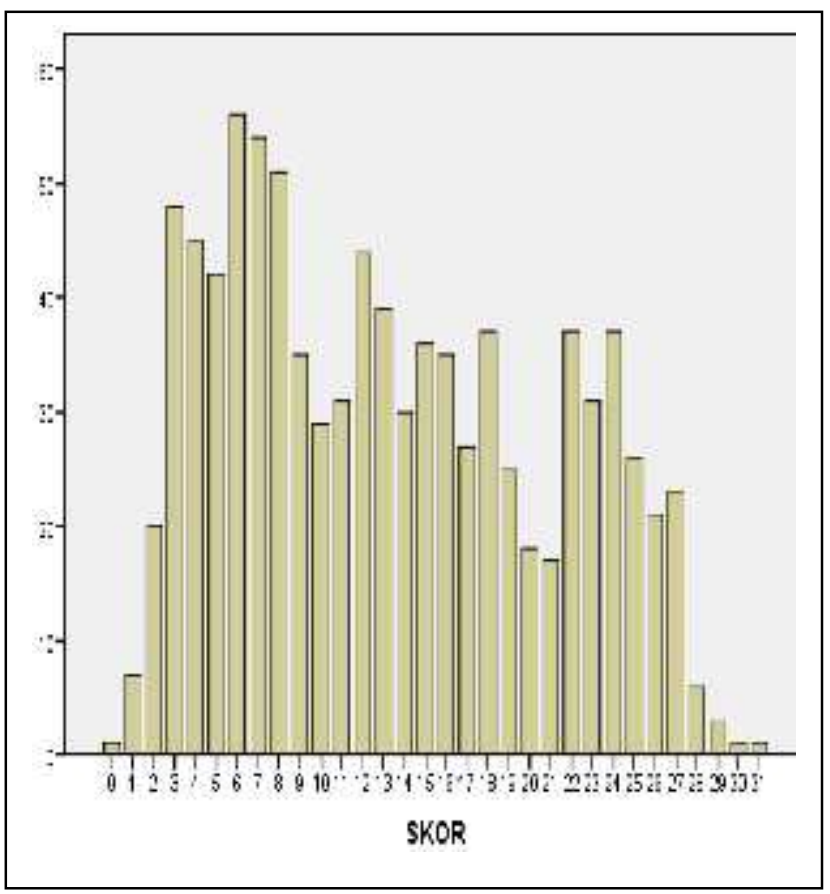

Gambar 3 Sebaran Skor KBTT

Tabel 5 Frekuensi Capaian Skor/Butir Soal

\begin{tabular}{rrrrr}
\hline \multirow{2}{*}{ Butir } & \multicolumn{5}{c}{ Skor } \\
\cline { 2 - 5 } & $\mathbf{0}$ & $\mathbf{1}$ & $\mathbf{2}$ & $\mathbf{3}$ \\
\hline 1 & 376 & 225 & 199 & 113 \\
$\left.2 \mathrm{a}^{*}\right)$ & 178 & 392 & 343 & - \\
$\left.2 \mathrm{~b}^{*}\right)$ & 191 & 340 & 382 & - \\
3 & 314 & 328 & 265 & 6 \\
4 & 387 & 185 & 311 & 30 \\
5 & 357 & 223 & 263 & 70 \\
6 & 225 & 263 & 215 & 210 \\
7 & 298 & 250 & 218 & 147 \\
$\left.8^{*}\right)$ & 311 & 351 & 251 & - \\
9 & 439 & 132 & 158 & 184 \\
10 & 392 & 224 & 227 & 70 \\
11 & 327 & 249 & 225 & 112 \\
\hline
\end{tabular}

Ket. *) skor maksimal 2. 


\section{SANG PENCERAH}

Volume 3, Nomor 1, Februari 2017, Hlm. 50-62

Samritin: Keterampilan Berpikir Tingkat Tinggi Siswa ...

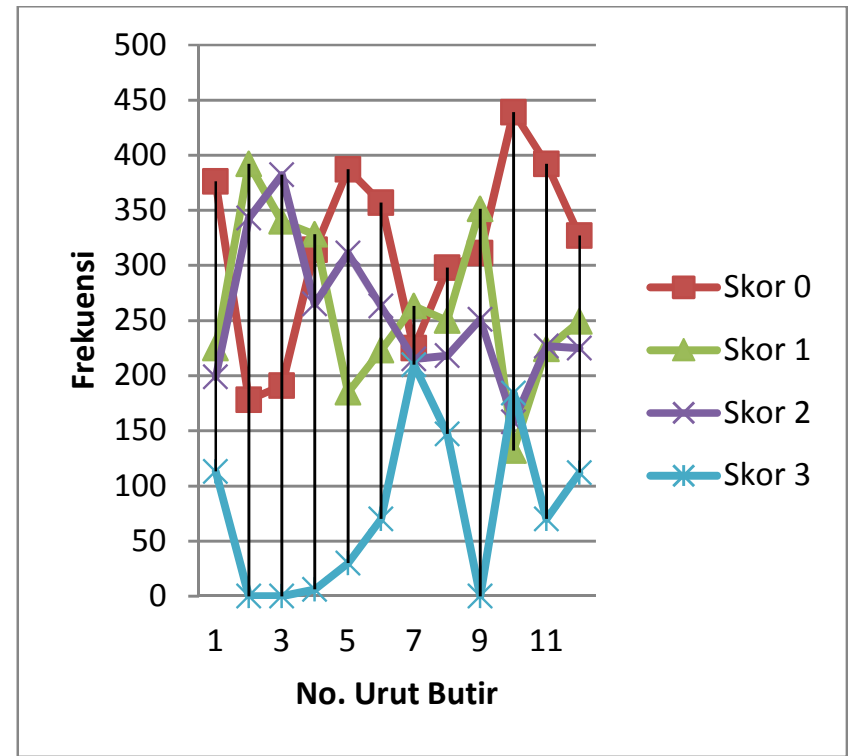

Gambar 4 Grafik Capaian Skor Setiap Butir Soal

Tabel 5 dan Gambar 5 menunjukkan bahwa frekuensi siswa yang memiliki skor 0 sangat tinggi pada setiap setiap soal. Frekuensi terendah siswa yang gagal menjawab soal hanya terjadi pada butir 2a sebanyak 178 atau $19,5 \%$ dan disusul oleh butir $2 \mathrm{~b}$ sebanyak 191 atau $20,9 \%$. Skor 0 dengan frekuensi sangat tinggi terjadi pada empat butir soal. Keempat butir tersebut yaitu butir 1 , butir 4 , butir 9 , dan butir 10. Siswa yang gagal menjawab soal atau memperoleh skor 0 pada keempat butir tersebut masing-masing lebih dari $40 \%$. Pada butir 1 sebanyak (1) 367 atau $41,2 \%$ siswa gagal menjawab soal, (2) 225 atau 224,6\% siswa hanya mencapai skor 1, (3) 199 atau 21,8\% mencapai skor 2 dan (4) hanya 113 atau 12,4\% siswa yang mampu menjawab secara tuntas. Butir 4 merupakan butir soal yang merepresentasekan materi Operasi pada Bentuk Aljabar dan termasuk dalam kategori soal level koneksi. Pada butir 4 sebanyak (1) 387 atau 42,4\% siswa gagal menjawab soal, (2) 185atau 20,3\% siswa hanya mencapai skor 1, (3) 311 atau $34,1 \%$ mencapai skor 2 dan (4) hanya 30 atau 3,3\% siswa yang mampu menjawab secara tuntas. Butir 4 merupakan butir soal yang merepresentasekan materi Relasi dan Fungsi dan termasuk dalam kategori soal level koneksi. Pada butir 9 sebanyak (1) 439 atau $48,1 \%$ siswa gagal menjawab soal, (2) 132 atau $14,5 \%$ siswa hanya mencapai skor 1 , (3) 158 atau 17,3\% mencapai skor 2 dan (4) 184 atau $20,2 \%$ siswa yang mampu menjawab secara tuntas. Pada butir 10 (nomor urut 11) sebanyak
(1) 392 atau $42,9 \%$ siswa gagal menjawab soal, (2) 224 atau $24,5 \%$ siswa hanya mencapai skor 1 , (3) 227 atau $24,9 \%$ mencapai skor 2 dan (4) hanya 70 atau $7,7 \%$ siswa yang mampu menjawab secara tuntas. Butir 9 dan butir 10 merupakan butir-butir soal yang merepresentasekan materi Sistem Persamaan Linier Dua Variabel dan termasuk dalam kategori soal level Penalaran dan Pemecahan Masalah.

Pada Tabel 5 dan Gambar 5 juga terlihat bahwa siswa yang mencapai skor maksimal pada setiap butir soal masing-masing tidak lebih dari $42 \%$. Butir-butir soal dengan skor maksimal 2 hanya dapat diselesaikan secara tuntas oleh $27,5 \%, 37,6 \%$ dan $41,8 \%$ siswa. Butir-butir soal yang memiliki skor maksimal 3 hanya bisa diselesaikan siswa secara tuntas tidak lebih dari $21 \%$ setiap butir. Kondisi ini mengakibatkan rendahnya capaian KBTT siswa. Penelusuran terhadap skor perolehan juga dilakukan pada capaian skor dan rerata skor setiap sub materi. Hasil penelusuran tersebut disajikan pada tabel berikut.

Tabel 6 Rerata Capaian Skor KBTT pada Setiap Sub Materi

\begin{tabular}{lrrrrr}
\hline Sekolah & OA & RF & NF & PGL & SPLDV \\
\hline SMPN1R & 1.03 & 3.29 & 2.03 & 1.52 & 5.24 \\
SMPN2R & 1.17 & 3.39 & 2.32 & 1.47 & 5.97 \\
SMPN3R & 0.59 & 3.15 & 1.60 & 1.23 & 3.97 \\
SMPN4R & 1.06 & 3.50 & 1.96 & 1.55 & 5.55 \\
SMPN5R & 1.07 & 3.23 & 1.45 & 1.19 & 4.40 \\
\hline
\end{tabular}

Keterangan:

$\mathrm{OA}=$ Operasi Bentuk Aljabar,

$\mathrm{RF}=$ Relasi dan Fungsi,

$\mathrm{NF}=$ Nilai Fungsi,

$\mathrm{PGL}=$ Persamaan Garis Lurus,

SPLDV $=$ Sistem Persamaan Linier Dua Variabel

Tabel 6 menunjukkan bahwa rerata skor tertinggi pada sub materi operasi pada bentuk aljabar dimiliki oleh kelompok siswa SMPN 2 Raha, dan rerata terendah dimiliki oleh kelompok peserta tes SMPN 3 Raha. Rerata skor pada sub materi operasi pada bentuk aljabar tertinggi masih berada di bawah 1,5 (rerata ideal sub materi). Pada sub materi Operasi Bentuk Aljabar hanya satu butir tes yang ditempuh oleh peserta tes yaitu butir 


\section{SANG PENCERAH}

Volume 3, Nomor 1, Februari 2017, Hlm. 50-62

\section{Samritin: Keterampilan Berpikir Tingkat Tinggi Siswa ...}

nomor 1. Skor maksimal pada butir tes hanya dicapai oleh 2,5\%, skor 2 dicapai oleh $8,9 \%$, sedangkan skor 1 dicapai $36,7 \%$ dan $51.9 \%$ memperoleh skor 0 atau gagal menjawab soal.

Rerata skor tertinggi yang ditunjukkan oleh tabel 4 pada sub materi Relasi dan Fungsi dicapai oleh kelompok peserta tes SMPN 4 Raha dan rerata skor terendah dimiliki oleh kelompok peserta tes SMPN 3 Raha. Pada sub materi Relasi dan Fungsi terdapat tiga butir tes yang ditempuh peserta tes yaitu butir 2a, 2b, dan 3. Pada butir 2a, 44,7\% siswa SMPN 4 Raha mencapai skor maksimal, (2) 35,8\% mencapai skor 1, dan selebihnya gagal menjawab soal. Pada butir $2 b, 48,4 \%$ siswa SMPN 2 Raha mencapai skor maksimal (2), dan $34,6 \%$ mencapai skor 1 , dan selebihnya memperoleh skor 0. Pada butir 3, hanya $0.6 \%$ siswa SMPN 4 Raha yang mencapai skor maksimal (3), skor 2 dan 1 masing-masing dicapai oleh $31,1 \%$, dan 36,5\% memperoleh skor 0. Berdasarkan persentase capaian tersebut terlihat bahwa meskipun peserta tes SMPN 4 Raha memperoleh rerata skor tertinggi pada Sub Materi Relasi dan Fungsi, tetapi lemah pada butir 3. Butir 3 merupakan salah satu butir tes yang mengungkap kemampuan koneksi matematika.

Rerata skor tertinggi pada sub materi Nilai Fungsi yang ditunjukkan tabel 4 dimiliki oleh kelompok siswa SMPN 2 Raha yaitu 2,32. Capaian skor siswa SMPN 2 Raha pada sub materi Nilai Fungsi yaitu (1) untuk butir 4: (a) hanya $5,1 \%$ siswa yang mencapai skor 3 , (b) $36,4 \%$ mencapai skor 2 , (c) $18,7 \%$ mencapai skor 1, dan (d) terdapat 39,8\% siswa yang memperoleh skor 0, (2) untuk butir 5: (a) hanya $11,7 \%$ siswa yang mencapai skor 3 , (b) $33,1 \%$ mencapai skor 2 , (c) $25 \%$ mencapai skor 1, dan (d) terdapat 30,1\% siswa yang memperoleh skor 0. Rerata skor terendah pada sub materi Nilai Fungsi dimiliki oleh kelompok siswa SMPN 5 Raha yaitu 1,45. Capaian skor siswa SMPN 5 Raha pada sub materi Relasi dan Fungsi yaitu (1) untuk butir 4: (a) hanya $2,0 \%$ siswa yang mencapai skor 3 , (b) $29,6 \%$ mencapai skor 2 , (c) $13,3 \%$ mencapai skor 1, dan (d) terdapat 55,1\% siswa yang memperoleh skor 0, (2) untuk butir 5: (a) hanya $3,1 \%$ siswa yang mencapai skor 3, (b) $18,4 \%$ mencapai skor 2 , (c) $25,5 \%$ mencapai skor 1 , dan (d) terdapat $53,1 \%$ siswa yang memperoleh skor 0 .

Rerata skor tertinggi pada sub materi Persamaan Garis Lurus pada tabel 4 dimiliki oleh kelompok siswa SMPN 4 Raha yaitu 1,55. Sub materi PGL diwakili oleh satu butir soal yaitu butir 6. Capaian skor siswa SMPN 4 Raha pada sub materi PGL yaitu (1) $28,1 \%$ siswa yang mencapai skor 3, (2) $24,5 \%$ mencapai skor 2, (3) 22\% mencapai skor 1, dan (d) terdapat $25,2 \%$ siswa yang memperoleh skor 0. Rerata skor terendah pada sub materi Persamaan Garis Lurus yang ditunjukkan tabel 4 dimiliki oleh kelompok siswa SMPN 5 Raha yaitu 1,19. Sub materi PGL diwakili oleh satu butir soal yaitu butir 6. Rincian capaian skor siswa SMPN 5 Raha pada sub materi PGL yaitu (1) hanya $14,3 \%$ siswa yang mencapai skor 3, (2) 23,5\% mencapai skor 2, (3) $30,6 \%$ mencapai skor 1 , dan (d) terdapat $31,6 \%$ siswa yang memperoleh skor 0 .

Rerata skor tertinggi pada sub materi Sistem Persamaan Linier Dua Variabel (SPLDV) yang ditunjukkan tabel 4 dimiliki oleh kelompok siswa SMPN 4 Raha yaitu 1,19. Sub materi PGL diwakili oleh 5 butir soal yaitu butir 7-12. Capaian skor siswa SMPN 4 Raha pada sub materi SPLDV yaitu (1) untuk butir 7: (a) hanya 18,2\% siswa yang mencapai skor 3, (b) 22,6\% mencapai skor 2, (c) 23,3\% mencapai skor 1 , dan (d) terdapat $35,8 \%$ siswa yang memperoleh skor 0 , (2) untuk butir 8: (a) hanya 39\% siswa yang mencapai skor 2 , (b) $20,1 \%$ mencapai skor 1, dan (c) $40,9 \%$ memperoleh skor 0, (3) untuk butir 9: (a) $30,8 \%$ siswa yang mencapai skor 3 , (b) $10,7 \%$ mencapai skor 2 , (c) $12,6 \%$ mencapai skor 1 , dan (d) terdapat $45,9 \%$ siswa yang memperoleh skor 0, (3) untuk butir 10: (a) hanya $9,4 \%$ siswa yang mencapai skor 3 , (b) $25,8 \%$ mencapai skor 2 , (c) $20,1 \%$ mencapai skor 1, dan (d) terdapat $44,7 \%$ siswa yang memperoleh skor 0, (4) untuk butir 11: (a) 


\section{SANG PENCERAH}

Volume 3, Nomor 1, Februari 2017, Hlm. 50-62

Samritin: Keterampilan Berpikir Tingkat Tinggi Siswa ...

hanya $11,9 \%$ siswa yang mencapai skor 3 , (b) $22 \%$ mencapai skor 2 , (c) $33,3 \%$ mencapai skor 1 , dan (d) terdapat $32,7 \%$ siswa yang memperoleh skor 0 .

Rerata skor terendah pada sub materi Sistem Persamaan Linier Dua Variabel (SPLDV) yang ditunjukkan dimiliki oleh kelompok siswa SMPN 3 Raha yaitu 1,19. Capaian skor siswa SMPN 3 Raha pada sub materi SPLDV yaitu (1) untuk butir 7: (a) hanya $11,4 \%$ siswa yang mencapai skor 3 , (b) $17,7 \%$ mencapai skor 2 , (c) $20,3 \%$ mencapai skor 1, dan (d) terdapat $50,6 \%$ siswa yang memperoleh skor 0, (2) untuk butir 8: (a) masing-masing 34,2\% siswa yang mencapai skor 2 dan 1, dan (b) 31,6\% mencapai skor 0, (3) untuk butir 9: (a) 3,8\% siswa yang mencapai skor 3, (b) 15,2\% mencapai skor 2, (c) $13,9 \%$ mencapai skor 1 , dan (d) terdapat $67,1 \%$ siswa yang memperoleh skor 0 , (3) untuk butir 10: (a) hanya $7,6 \%$ siswa yang mencapai skor 3, (b) 12,7\% mencapai skor 2, (c) 25,3\% mencapai skor 1 , dan (d) terdapat $44,4 \%$ siswa yang memperoleh skor 0, (4) untuk butir 11: (a) hanya $6,3 \%$ siswa yang mencapai skor 3, (b) 10,1\% mencapai skor 2, (c) $49,4 \%$ mencapai skor 1 , dan (d) terdapat $34,2 \%$ siswa yang memperoleh skor 0 .

Uraian capaian skor dan rerata skor di atas menunjukkan bahwa setiap sekolah yang memiliki rerata skor tertinggi semuanya memiliki persentase yang rendah. Sebaliknya persentase siswa yang mencapai skor-skor rendah mendominasi pada setiap butir soal. Hal ini berarti bahwa rendahnya capaian KBTT bukan hanya dihasilkan oleh siswasiswa dari sekolah-sekolah yang rendah rerata skornya tetapi juga oleh siswa yang berasal dari sekolah-sekolah yang memiliki rerata capain tinggi pada setiap materi.

Hasil analisis reliabilitas menunjukkan bahwa tingkat kepercayaan hasil pengukuran sangat tinggi. Tingkat kepercayaan ini terlihat dari koefisien reliabilitas antarpenilai yang hampir mancapai 1,00 dan koefisien reliabilitas konsistensi internal yang mencpai
0,87. Tingginya reliabilitas konsistensi antarpenilai dan koefisien reliabilitas konsistensi internal mengindikasikan bahwa kedua penilai yang dilibatkan dalam penelitian ini telah melakukan penilaian/pemberian skor sesuai dengan paedoman penskoran yang disediakan. Kondisi ini juga berarti bahwa perbedaan interpretasi terhadap jawaban siswa sangat kecil. Kecilnya perbedaan penafsiran tersebut merupakan konsekuensi logis dari keberfungsian pedoman penskoran yang disediakan. Hal ini berarti bahwa pedoman penskoran yang menyertai instrumen penelitian ini memiliki tingkat kepercayaan yang sangat tinggi. Koefisien reliabilitas konsistensi internal yang mencapai 0,87 dalam penelitian ini menggambarkan bahwa instrumen (tes) yang digunakan dalam penelitian ini memiliki tingkat kepercayaan yang tinggi. Dengan demikian hasil pengukuran KBTT dalam penelitian ini memiliki tingkat kepercayaan yang sangat tinggi.

Dominannya peserta tes yang berketerampilan di bawah rata-rata ideal atau berketerampilan rendah dan sangat rendah dapat disebabkan oleh ketidakbiasaan siswa menempuh soal-soal matematika yang menuntut keterampilan berpikir tingkat tinggi. Dari hasil analisis terhadap skor-skor perolehan terhadap butir-butir tes ditemukan bahwa siswa sangat sedikit yang mampu menyelesaikan soal secara tuntas. Hal ini terlihat dari rendahnya persentase siswa yang mencapai skor maksimal pada setiap butir. Salah satu faktor yang menyebabkan rendahnya persentase siswa yang capaian skor maksimal adalah siswa tidak mencantumkan kesimpulan dari soal yang dijawab (untuk soal-soal yang membutuhkan kesimpulan). Melalui penelusururan skor capaian terhadap beberapa butir soal ditemukan bahwa sangat banyak siswa yang gagal menjawab soal. Pada butir-butir tertentu siswa yang memperoleh skor 0 memiliki persentase yang sangat tinggi. 


\section{SANG PENCERAH}

Volume 3, Nomor 1, Februari 2017, Hlm. 50-62

Samritin: Keterampilan Berpikir Tingkat Tinggi Siswa ...

\begin{abstract}
Rendahnya capaian siswa dalam menempuh soal-soal Higher Order Thinking mengindikasikan bahwa pengembangan keterampilan berpikir siswa dalam pembelajaran di kelas tidak maksimal. Siswa perlu dibiasakan untuk memecahkan berbagai masalah yang menuntut kemampuan tinggi. Masalah-masalah yang disuguhkan kepada siswa perlu dikemas dalam berbagai bentuk dan konteks. Soal-soal divergen perlu dikenalkan bukan hanya soal-soal konvergen. Siswa juga perlu dibiasakan untuk menyelesaikan masalah sampai pada pengambilan kesimpulan. Dengan demikian, potensi berpikir siswa dapat berkembang secara maksimal.
\end{abstract}

\section{Simpulan}

Simpulan penelitian ini bahwa (1) keterampilan berpikir tingkat tinggi siswa SMP dalam mata pelajaran masih rendah yang ditunjukkan oleh persentase siswa yang berada pada kategori rendah dan sangat rendah sebanyak $66,05 \%$, sedangkan siswa yang mencapai kategori tinggi dan sangat tinggi hanya sebanyak 33,95\%; (2) Persentase siswa yang mencapai kategori tinggi dan sangat tinggi di SMPN 4 Raha lebih tinggi dibandingkan siswa SMP lainnya; dan (3) Rerata skor setiap sekolah berada di bawah rerata ideal.

\section{Daftar Pustaka}

Allen, M.J. \& Yen, W.M. 1979. Introduction to Measurement Theory. Monterey, CA: Brooks/Cole Publishing Company.

Azwar, S. 2009. Penyusunan skala psikologi (Cetakan XII). Yogyakarta: Pustaka Pelajar.

Bissel, A.N. \& Lomens, P.P. 2006. A New Method for Assessing Critical Thinking in The Classroom [Versi elektronik]. BioScience, 56 (1), 66 -72.

Fraenkel, J.R. \& Wallen, N.E. 2008. How to Design and Evaluate Research in Education (Seventh Edition). Aucland, New York: McGraw-Hill.

Haertel, E.H. 2006. Reliability. Dalam R.L. Brennan (Eds.). Educational Measurement. (4th ed.). (pp. 65-110). USA: American Council On Education and Praeger Publishers.

Hopson, M.H., Simms, R.L., \& Knezek, G.A. 2001. Using A Technology Enriched Environment To Improve Higher-Order Thinking Skills [Versi elektronik]. Journal of Research on Technology in Education, 34(2), 109-119.

Kaur, B. \& Lam, T.T. (Eds.). 2012. Reasoning, Communication And Connections In Mathematics. Singapore: World Scientific.

Limbach, B. \& Waugh, W. 2013. Developing Higher Level Thinking [versi elektronik]. Journal of Instructional Pedagogies, 1-9.

McCurry, D. 2013. A High Degree Of Difficulty Assessing Higher Order Thinking In CrossCurricular Tests With Multiple Choice Items, 1-14. Diambil tanggal 6 Juni 2015 dari http://www.iaea.info/documents/ paper_2b7130e3.pdf

McMahon, G. 2009. Critical Thinking And Ict Integration In A Western Australian Secondary School [Versi elektronik]. Educational Technology \& Society, 12(4), 269-281.

Moore, B. \& Stanley, T. 2010. Critical Thinking And Formative Assessment. Albany, New York: Eye On Education. 


\section{SANG PENCERAH}

Volume 3, Nomor 1, Februari 2017, Hlm. 50-62

Samritin: Keterampilan Berpikir Tingkat Tinggi Siswa ...

Nunnally, J.C. 1981. Psychometric Theory. New Delhi: McGraw Hill.

Remirez, R.P.B. \& Ganaden, M.S. 2008. Creative Activities And Students' Higher Order Thinking Skills. Education Quarterly, 66 (1), 22-33.

Samritin. 2016. Developing An Assessment Instrument Of Junior High School Students' Higher Order Thinking Skills In Mathematics. Reid Journal, 2(1), 92107.

Sezer, R. 2008. Integration Of Critical Thinking Skills Into Elementry School Teacher Education Courses In Mathematics [Versi elektronik]. Education, 128(3), 349 $-362$.

Snyder, L.G. \& Snyder, M.J. 2008. Teaching Critical Thinking And Problem Solving Skills [Versi elektronik]. The Delta Pi Epsilon Journal, L(2), 90-100.

Sutherland, J. (July 2006). Promoting Group Talk and Higher-Order Thinking In Pupils By Coaching Secondary English Trainee Teachers. Literacy, 40(2), 106114. 